\title{
Influence of Rootstocks on Leaf Mineral Content in the Subtropical Peach cv. UFSun
}

\author{
Shirin Shahkoomahally and Jose X. Chaparro \\ Department of Horticultural Sciences, University of Florida, Gainesville, FL \\ 32611
}

Thomas G. Beckman

U.S. Department of Agriculture, Agricultural Research Service, Southeastern

Fruit and Tree Nut Research Laboratory, Byron, GA 31008

\section{Ali Sarkhosh \\ Department of Horticultural Sciences, University of Florida, Gainesville, FL 32611}

Additional index words. Florida peach, leaf analysis, macro- and micronutrients, mineral analysis, peach rootstock

\begin{abstract}
The rootstock is an essential element for orchard management, influencing scion growth, nutrient concentration, and fruit quality. Seasonal variations in leaf nutrients of 'UFSun' grafted on five different rootstocks ('Flordaguard', 'Barton', 'MP-29', 'P-22', and 'Okinawa') were investigated during the 2017-18 growing season in Citra, FL. There was no significant variation in the macronutrient concentrations $(N, P$, $\mathrm{K}, \mathrm{Mg}, \mathrm{Ca}$, and S) among different rootstocks; however, 'UFSun' on 'Okinawa' and 'Flordaguard' showed greater concentrations of $\mathrm{Ca}, \mathrm{K}$, and $\mathrm{Mg}$ concentration than other rootstocks. In contrast, 'Flordaguard' showed less potential to accumulate $P$ as compared with other rootstocks. The Ca concentration was lowest in 'MP-29' and 'Barton' in April and June. The concentration of macronutrients ( $\mathrm{N}, \mathrm{P}, \mathrm{K}, \mathrm{Mg}, \mathrm{Ca}$, and $\mathrm{S}$ ) in leaves was greater in April and October than in December and June. With respect to rootstocks, macronutrients in December and June were the highest in 'Okinawa' and the lowest in 'Barton'. In April, the lowest concentration of macronutrient was recorded in 'Barton', whereas the highest concentrations were found in 'P-22', 'Okinawa', and 'Flordaguard'. The highest leaf micronutrient concentrations were found in 'MP-29' and 'Barton', and the lowest in 'Okinawa' and 'Flordaguard' in June and October. For all rootstocks, concentrations of micronutrients increased between leaf growth in April and senescence in October. The micronutrient concentrations of leaves decreased during December. The widest dynamic changes during the vegetative cycle were found on ' $P-22$ '. Seasonal trends were more consistent for micronutrients than for macronutrients.
\end{abstract}

Rootstocks have greatly influenced fruit orchard management by affecting many horticultural characteristics, including fruit quality, leaf nutrient status, soil adaptation, tree growth and size, root shape and depth, cold tolerance, and resistance to various diseases (Castle, 1987; Chatzissavvidis et al., 2005). The appropriate rootstock contributes to optimal nutrient absorption and translocation, and enables reduction in the amounts of fertilizers applied, so it reduces the risk of nutrient leaching and possible toxicity, without decreasing fruit quality and yield (Jimenes et al., 2018; Zhang et al., 2010).

Received for publication 17 Oct. 2019. Accepted for publication 16 Dec. 2019.

Published online 24 February 2020.

A.S. is the corresponding author. E-mail: sarkhosha@ ufl.edu.

This is an open access article distributed under the CC BY-NC-ND license (https://creativecommons. org/licenses/by-nc-nd/4.0/). ple, it has been reported that, regardless of $\mathrm{N}$ fertilizer application, apple trees grafted on M.9 rootstock were more efficient in $\mathrm{N}$ uptake than when propagated on other stocks (Aguirre et al., 2001). Also, higher $K$ concentrations were reported in leaves of 'Golden Delicious' apple on M.7 EMLA rootstock than when propagated on other stocks (Fallahi et al., 2002). Numerous studies have demonstrated that rootstocks can affect fruit quality and scion leaf mineral concentration (Boyhan et al., 1995; Durán-Zuazo et al., 2005; Facteau et al., 1996; Knowles et al., 1984; Kviklys et al., 2012; North and Cook, 2006; Rosati et al., 1996; Tomala et al., 2008; Tsipouridis and Thomidis, 2005; Wünsche et al., 2005).

Given the documented effects of rootstock on tree growth, fruit production, and leaf mineral composition of other tree species, we aimed to investigate the effect of various rootstocks on leaf mineral composition of peach cv. UFSun grown under identical conditions. We hypothesized that various rootstocks with contrasting genetic origins would also influence leaf nutrient concentrations of peach cv. UFSun. The other goal of the present study was to evaluate seasonal variations in leaf nutrient concentrations to calculate accurate nutrient needs for the growing season in subtropical conditions in Florida.

\section{Materials and Methods}

Plant material and growing conditions The experiment was carried out on 5-yearold peach cv. UFSun peach budded onto five rootstocks (Table 1) at the Experimental Station of the Plant Science Research and Education Unit of the University of Florida located in Citra, FL (lat. $29^{\circ} 24^{\prime} 42.01^{\prime \prime} \mathrm{N}$; long. $\left.-82^{\circ} 06^{\prime} 36.00^{\prime \prime} \mathrm{W}\right)$. The predominant soil is Entisol, including fine sand (hyperthermic, uncoated, Typic Quartzipsamment) rich in carbonate with alkaline $\mathrm{pH}$ (Mylavarapu et al., 2016). Monthly averages of minimum, medium, and maximum air temperatures $\left({ }^{\circ} \mathrm{C}\right)$; air relative humidity $(\%)$; and monthly total rainfall $(\mathrm{mm})$ were recorded by the Florida Automated Weather Network weather station located on site (Table 2). Peach trees were planted at a spacing of a $6 \times 4-\mathrm{m}$ spacing and trained to an open-vase system to prevent vigor interferences between adjacent trees. Fertilization and winter pruning were applied as in a commercial orchard. Fertilization rates applied were $10 \mathrm{~N}-4.4 \mathrm{P}$ $8.3 \mathrm{~K}$, without any $\mathrm{Fe}$ chelate application. The orchard was irrigated with a dose of $0.049 \mathrm{~L} / \mathrm{h}$ per day during the summer.

The results are essential for the accurate application of fertilizer (Küçükyumuk et al., 2012).

In recent years, it has been well documented that good rootstocks along with precise nutrient applications can significantly affect fruit quality and yield (Amiri and Fallahi, 2009; Fallahi et al., 2002). Rootstocks can greatly affect the scion health and make it more tolerant of diverse conditions, via absorption of water and nutrients, and synthesis of hormones. In addition, rootstocks can affect the mineral nutrient levels in the scion (Ahmed et al., 2007). For exam-

\section{Leaf mineral analysis}

Sample collection. The leaf concentrations of macro- and micronutrients $(\mathrm{N}, \mathrm{P}, \mathrm{K}$, $\mathrm{Ca}, \mathrm{Mg}, \mathrm{S}, \mathrm{Fe}, \mathrm{Mn}, \mathrm{Cu}, \mathrm{Zn}$, and B) in 'UFSun' peach trees were evaluated in the 2017 and 2018 growing season. Leaf samples were taken in the Winter (December), Spring (April), Summer (June), and Fall (October). Leaves were collected from each replicate and from each cardinal direction (North, East, South, and West), around the canopy 


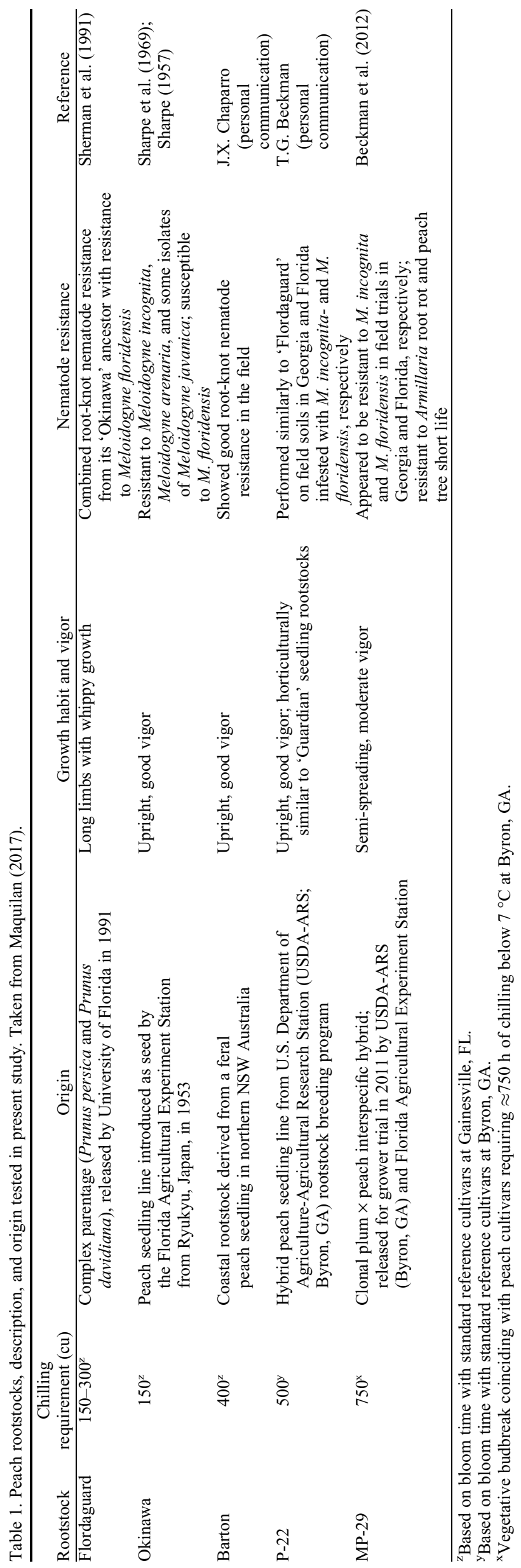

of the tree. Fully expanded leaf samples were collected from the middle portion of current season shoots situated in the middle third of the plant. The fully expanded leaves including the blade and petiole were sampled in each experimental block. A total of 64 leaves were collected in each sampled plot. The experiment was established in a factorial randomized block design with replications of each treatment combination with two trees per experimental plot $(6$ replications $\times 5$ rootstock treatments $\times 2$ trees per plot for a total of 60 trees for data collection), with the basic plot consisting of two trees per scionrootstock combination. Guard rows were used to preclude possible edge effects.

Sample preparation. Samples were examined to determine physical condition and freedom from disease, and extent of contamination. Petioles, stems, and any foreign materials were removed and the leaves rinsed, then placed in an oven and dried for $48 \mathrm{~h}$ at $60{ }^{\circ} \mathrm{C}$. Afterward, the dried sample was ground in a Wiley Model 4 Mill (Thomas Scientific, Swedesboro, NJ) to pass a 20 mesh $(1.00-\mathrm{mm})$ screen; 0.50 -g samples were weighted, placed in a tube, and $5 \mathrm{~mL}$ nitric acid $(70 \%)$ was added to each sample. The tubes were incubated at $95{ }^{\circ} \mathrm{C}$ for $90 \mathrm{~min}$. Following this treatment, $4 \mathrm{~mL}$ of $30 \%$ hydrogen peroxide was added to each tube. After the reaction subsided, samples were incubated for $20 \mathrm{~min}$ at $95^{\circ} \mathrm{C}$ and then cooled for $2 \mathrm{~min}$. Each tube was brought to the $50-\mathrm{mL}$ volume mark with deionized water and mixed well, filtered through a paper filter, and transferred to ICP tubes for analysis. An ICAP-Open vessel wet digestion Digi Block 3000 " was used for tissue analysis (Waters Agricultural Laboratories Inc., Camilla, GA) (Isaac and Johnson, 1985).

\section{Deviation from optimum percentage index}

The deviation from optimum percentage (DOP index) was calculated for the diagnosis of the leaf mineral status according to Montañés et al. (1991). The DOP index was estimated from the leaf analysis by the following formula:

$$
D O P=\frac{C \times 100}{C r e f}-100,
$$

where $C$ is the nutrient concentration in the sample to be studied, and Cref is the nutrient concentration considered as optimum, based on dry matter. The Cref has been proposed from the optimum values by Reuter (1997). A negative DOP index indicates a deficiency, whereas a positive DOP index indicates an excess (Kumar et al., 2017). The $\Sigma$ DOP is obtained by adding the values of DOP indices irrespective of sign.

\section{Statistical design and analysis}

Data obtained from this study were performed using SAS version 11.0 (SAS Institute Inc., Cary, NC). One-way analysis of variance was analyzed with different rootstocks as the main effect and replicate as a random effect in a completely randomized plot analysis to determine the difference among rootstocks. Differences 
among means were determined using least significant difference test at $P$ value of 0.05 with Duncan's honest significant difference test. Pearson correlation matrix method was determined to study correlations among all rootstocks evaluated. A principal component analysis (PCA) was performed to evaluate interrelationships among rootstocks. Also, rootstock means were used in a multivariate analysis to generate two-way similarity cluster diagrams based on rootstock similarity and variability.

\section{Results}

Rootstock effects on seasonal leaf mineral element concentrations. The levels of all elements in scion leaf tissue were influenced by the rootstock used in different months (Fig. 1). In general, the concentrations of macroelements in scion leaves were higher in April and October than those in December and June. As for rootstock effects on macronutrients, levels were generally higher in December and June on 'Okinawa' and lowest on 'Barton'. However, in April, the lowest macroelement concentrations was recorded on 'Barton', whereas the highest concentration was found on 'P-22', 'Okinawa', and
'Flordaguard' (Fig. 1). The mean concentrations of macro- and microelements from mature leaf samples collected in 2017 and 2018 for each rootstock treatment are shown in Table 3. However, differences among rootstock cultivar treatments for macronutrient concentration were not significant in most of the cases. The impact of different rootstocks on leaf macronutrient concentration in the scion was not consistent. 'Okinawa' had the higher concentration of leaf $\mathrm{Ca}$ and $\mathrm{K}$ of the scion than other rootstocks in December, April, and June. Leaf calcium concentration was lowest on 'MP-29' in December and April (Table 3).

For all rootstocks, scion leaf concentrations of microelements increased between emergence in April and senescence in October of the leaves. Concentration of micronutrients decreased during December, and then increased through the growing season until October on all rootstocks. It would appear that seasonal dynamics of microelements had a more consist trend than did macroelements. Generally, micronutrient concentration ( $\mathrm{B}, \mathrm{Zn}, \mathrm{Mn}, \mathrm{Fe}, \mathrm{Cu})$ was the highest in 'Barton' and 'MP-29' in June and October. Since that period, the micronutrient concentration was decreasing in 'Okinawa' and 'Flordaguard'. The widest change in nutrient concentrations during the vegetative cycle was noted on 'P-22' (Fig. 1). The highest $\mathrm{Cu}$ concentration was detected in 'UFSun' trees budded on 'Okinawa', and the lowest in 'Barton' in April, June, and October (Fig. 1); however, in most cases, differences in micronutrient concentrations were not statistically significant (Table 3 ). 'MP-29' had the highest concentration of $\mathrm{Fe}$ in most months, as opposed to the lowest on 'Okinawa' and 'Flordaguard'. Leaf Zn concentration in December was highest on 'Okinawa', and lowest on 'Okinawa' and 'Flordaguard' in October. The highest concentration of B was detected on 'P-22' in October and the lowest on 'Flordaguard' and 'MP-29' in December (Table 3).

Impact of various rootstocks on DOP. Rootstocks affected the DOP index of leaf tissue. In spite of the negative values in absolute terms, trees on 'Okinawa' and 'Flordaguard' were more nutritionally balanced than those on 'Barton' and 'MP-29' rootstocks (Fig. 2). The highest $\Sigma$ DOP index values in macronutrients (Fig. 2) were detected on 'Okinawa' and 'Flordaguard' in

Table 2. Monthly total rainfall $(\mathrm{mm})$; monthly mean maximum, minimum, and medium temperatures $\left({ }^{\circ} \mathrm{C}\right)$; air relative humidity $(\%)$; and monthly accumulated chilling hours $\left(0\right.$ to $\left.7.2^{\circ} \mathrm{C}\right)$ in 2017 and 2018, in Citra, FL. Source: Florida Automated Weather Network (FAWN) weather station located on site at the Plant Science Research and Education Unit; https://fawn.ifas.ufl.edu/.

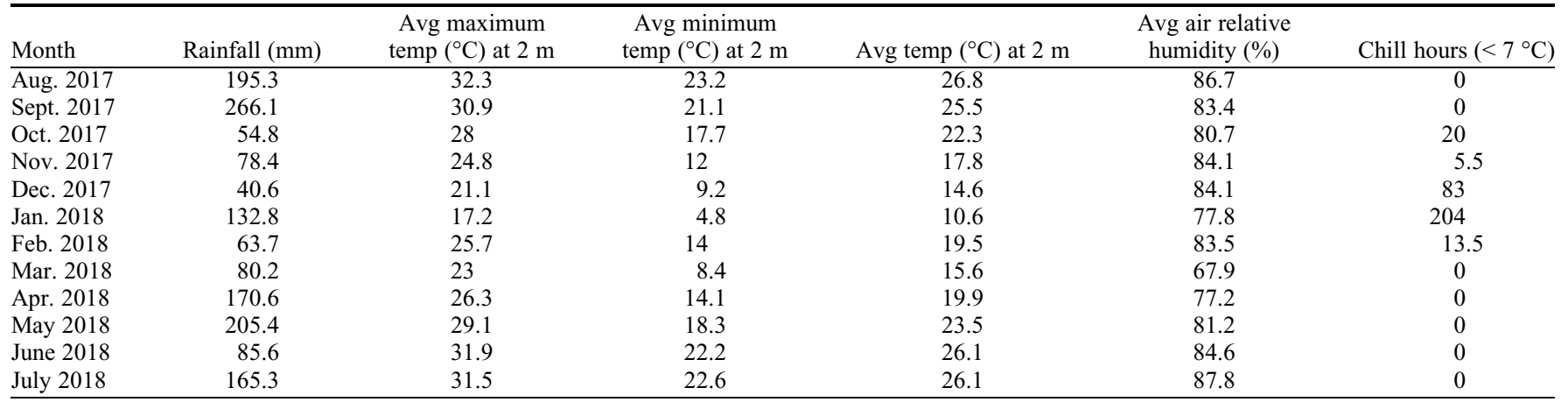

A

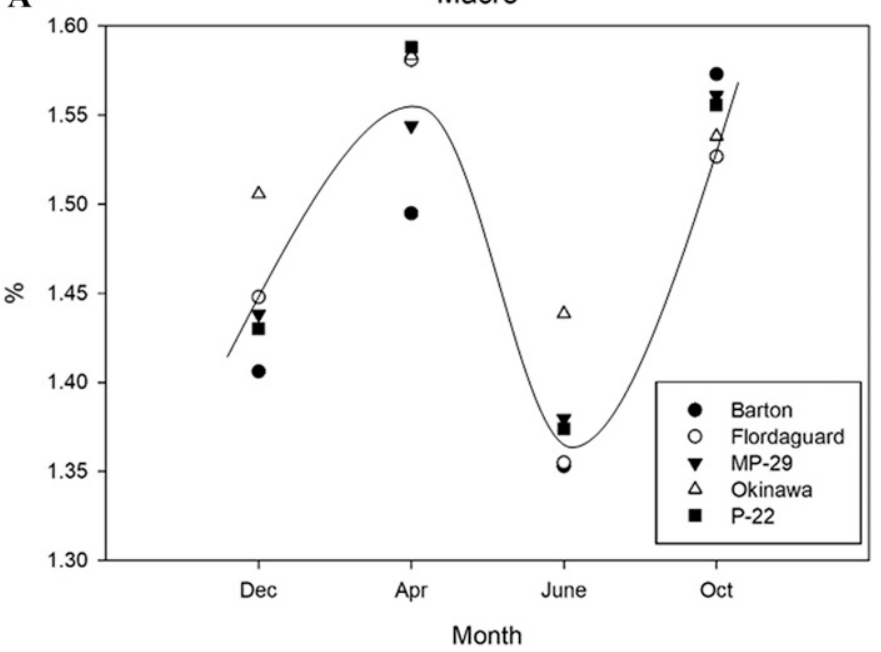

B

Micro

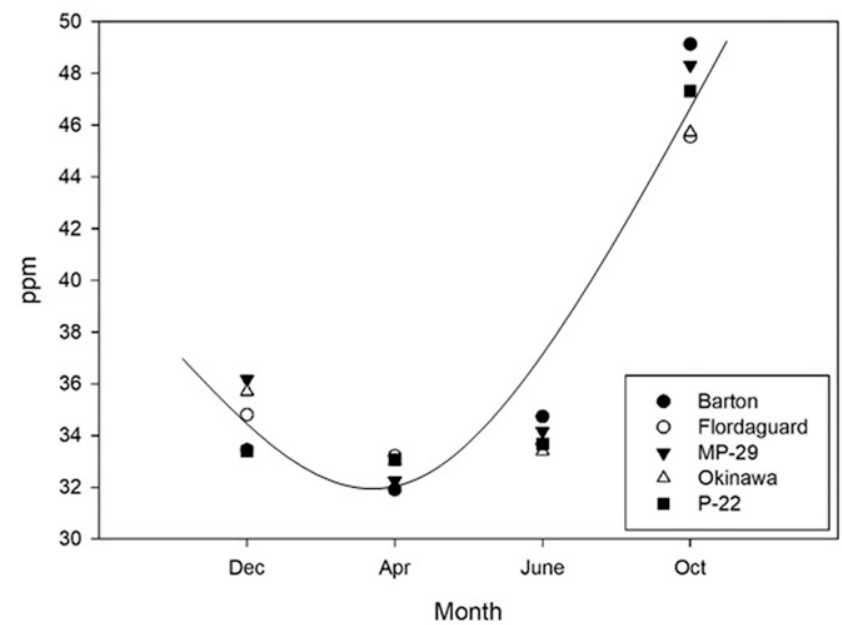

Fig. 1. Seasonal changes of macronutrient (A) and micronutrient (B) concentrations in the 'UFSun' peach leaf tissue during the months of December, April, June, and October. 


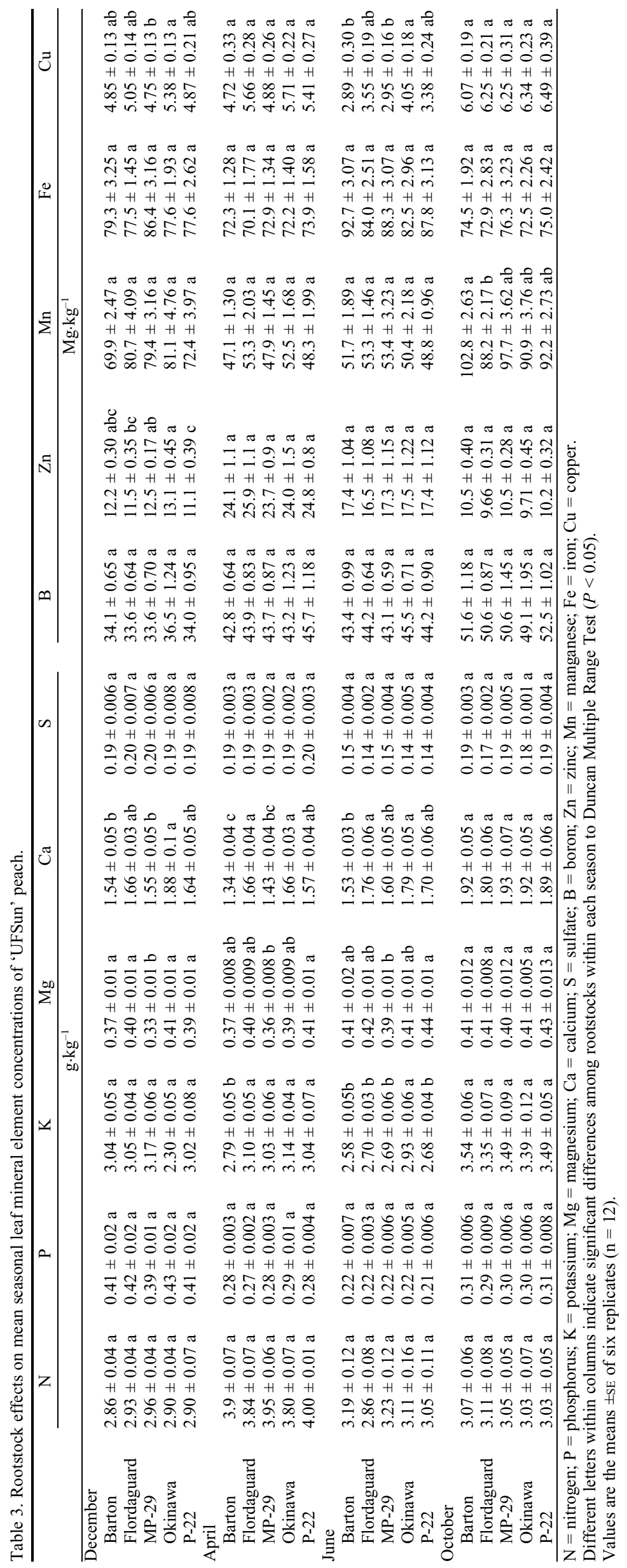

December, suggesting a high leaf nutrient imbalance, whereas the lowest values were obtained on 'Flordaguard' in April and June. The highest DOP index values in macronutrients were determined for $\mathrm{P}$ on 'Okinawa' and 'Flordaguard' in December, whereas the lowest values were obtained on 'Flordaguard' in April. DDOP index for macronutrients varied across sampling dates. 'Okinawa' and 'Flordaguard' had better balanced nutritional values than Barton' and 'MP-29', probably because of their better mineral uptake efficiency. In the case of seasonal variation, best-balanced and the wider imbalance nutritional value for macro- and microelements were in October and June, respectively (Fig. 2).

The lowest $\Sigma$ DOP index (i.e., the most strongly balanced micronutrient concentration) was observed on 'P-22' and 'Barton' in April and June. In micronutrients, the DOP index was highest for B on 'P-22' in October (Table 4). In micronutrients, the $\Sigma$ DOP index was highest on 'Barton', 'Okinawa', and 'MP-29' in October, resulting in the highest imbalance in terms of the concentration of those nutrients. With regard to micronutrients (Table 4), the DOP index shows a deficiency of $\mathrm{Mg}, \mathrm{Fe}$, and $\mathrm{Zn}$ in December and October on all rootstock treatments. The highest leaf $\mathrm{Fe}$ deficiency was detected in 'Okinawa' and 'Flordaguard' across all sampling dates. The highest deficiencies (relative to optimum values) of $\mathrm{Mg}$ were detected for leaf $\mathrm{Mg}$ on 'MP-29' in December. The lowest leaf Ca deficiency was observed on 'MP-29' in April and the highest on 'Barton' in December. The concentration of $\mathrm{Cu}$ was below optimum values and showed a deficiency on all rootstocks; however, 'Okinawa' and 'Flordaguard' generally exhibited a smaller deficiency than other rootstocks. Below optimal B was observed on all rootstocks only in December (Table 4).

Biplot and clustering. Various traits were analyzed on the first PC (Fig. 3) that indicated moderate correlations with $\mathrm{Mg}, \mathrm{Ca}$, $\mathrm{Mn}, \mathrm{S}$, and $\mathrm{Cu}$; however, the second $\mathrm{PC}$ showed a high correlation with $\mathrm{S}$ and $\mathrm{N}$. Thereby, results presented that 'MP-29' and 'Barton', on the negative side of $\mathrm{PC} 1$, had higher $\mathrm{S}, \mathrm{N}$, and $\mathrm{Fe}$, and lower $\mathrm{Ca}, \mathrm{Cu}, \mathrm{B}$, $\mathrm{Mg}$, and $\mathrm{P}$, whereas 'Okinawa', 'Flordaguard', and 'P-22' induced the contrary. In the case of macronutrients, 'Okinawa' had the most macronutrient uptake with the highest frequency, in contrast to 'MP-29' and 'Barton' (Fig. 3).

Through a hierarchical agglomerative cluster analysis, the rootstocks were divided into groups of increasing dissimilarity. Two clusters were identified in leaf samples (Fig. 4) with quite diverse cluster. In term of leaf nutrient concentrations, 'MP-29' and 'Barton', as the first group (Fig. 4), were characterized by high N, Fe, $\mathrm{S}$, and $\mathrm{Zn}$ values, and medium to low $\mathrm{Ca}$, $\mathrm{Cu}, \mathrm{Mg}$, and $\mathrm{B}$ values. 'Okinawa', 'P-22', 
Macronutrients (A)

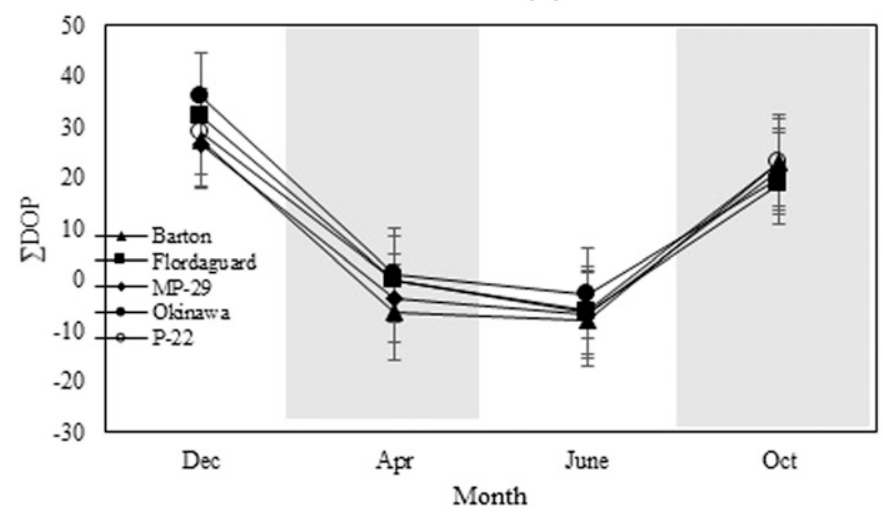

Micronutrients (B)

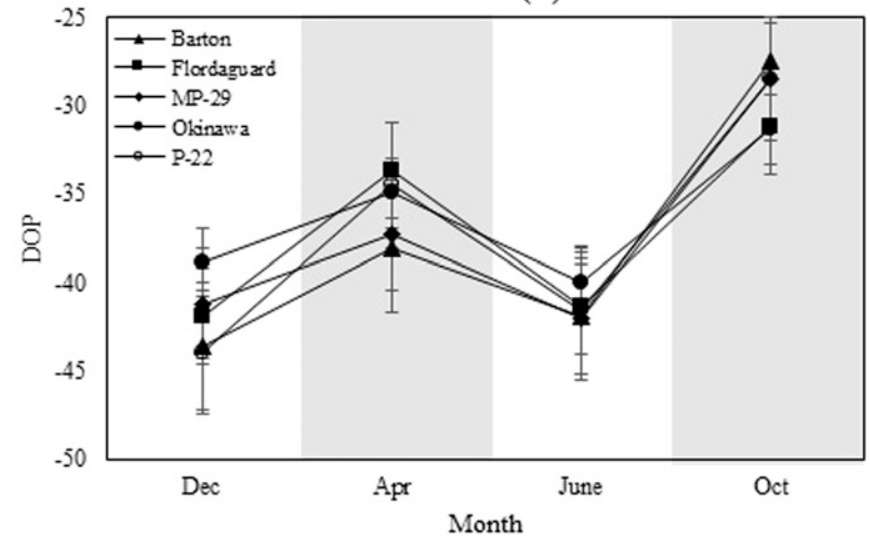

Fig. 2. Sigma deviation from the optimum percentage ( $\Sigma$ DOP index) determined from leaf macronutrient $(\mathbf{A})$ and micronutrient (B) levels at various months of 'UFSun' cultivar grafted on five rootstocks. Values are the mean.

Table 4. Impact of various rootstocks on deviation from the optimum percentage (DOP index) of 'UFSun' peach leaf at different months. Values are the mean.

\begin{tabular}{|c|c|c|c|c|c|c|c|c|c|c|}
\hline & $\mathrm{N}$ & $\mathrm{P}$ & $\mathrm{K}$ & $\mathrm{Mg}$ & $\mathrm{Ca}$ & B & $\mathrm{Zn}$ & $\mathrm{Mn}$ & $\mathrm{Fe}$ & $\mathrm{Cu}$ \\
\hline & \multicolumn{5}{|c|}{$\%$} & \multicolumn{5}{|c|}{ ppm } \\
\hline \multicolumn{11}{|l|}{$\overline{\text { December }}$} \\
\hline Barton & $-5.7 \mathrm{a}$ & $173.9 \mathrm{a}$ & $51.4 \mathrm{a}$ & $-55.4 \mathrm{a}$ & $-28.0 \mathrm{~b}$ & $-14.7 \mathrm{a}$ & $-65.0 \mathrm{abc}$ & $-30.1 \mathrm{a}$ & $-54.7 \mathrm{a}$ & $-53.8 \mathrm{ab}$ \\
\hline Flordaguard & $-3.6 \mathrm{a}$ & $185.0 \mathrm{a}$ & $52.2 \mathrm{a}$ & $-51.7 \mathrm{a}$ & $-22.4 \mathrm{ab}$ & $-15.9 \mathrm{a}$ & $-67.0 \mathrm{bc}$ & $-19.3 \mathrm{a}$ & $-55.7 \mathrm{a}$ & $-51.8 \mathrm{ab}$ \\
\hline MP-29 & $-2.5 \mathrm{a}$ & $166.1 \mathrm{a}$ & $57.8 \mathrm{a}$ & $-60.6 \mathrm{~b}$ & $-27.4 b$ & $-16.0 \mathrm{a}$ & $-64.1 \mathrm{ab}$ & $-20.5 \mathrm{a}$ & $-50.6 \mathrm{a}$ & $-54.7 \mathrm{~b}$ \\
\hline Okinawa & $-4.5 \mathrm{a}$ & $187.2 \mathrm{a}$ & $59.3 \mathrm{a}$ & $-51.2 \mathrm{a}$ & $-11.7 \mathrm{a}$ & $-8.6 \mathrm{a}$ & $-62.6 \mathrm{a}$ & $-18.9 \mathrm{a}$ & $-55.5 \mathrm{a}$ & $-48.7 \mathrm{a}$ \\
\hline P-22 & $-4.5 \mathrm{a}$ & $175.2 \mathrm{a}$ & $50.6 \mathrm{a}$ & $-52.5 \mathrm{a}$ & $-23.3 \mathrm{ab}$ & $-14.9 \mathrm{a}$ & $-68.1 c$ & $-27.6 \mathrm{a}$ & $-55.6 \mathrm{a}$ & $-53.6 \mathrm{ab}$ \\
\hline \multicolumn{11}{|l|}{ April } \\
\hline Barton & $3.4 \mathrm{a}$ & $8.0 \mathrm{a}$ & $4.4 \mathrm{~b}$ & $-37.8 \mathrm{ab}$ & $-10.0 \mathrm{c}$ & $7.2 \mathrm{a}$ & $-30.9 \mathrm{a}$ & $-52.9 \mathrm{a}$ & $-58.7 \mathrm{a}$ & $-55.0 \mathrm{a}$ \\
\hline Flordaguard & $0.2 \mathrm{a}$ & $5.8 \mathrm{a}$ & $15.8 \mathrm{a}$ & $-33.9 \mathrm{ab}$ & $11.8 \mathrm{a}$ & $9.9 \mathrm{a}$ & $-25.7 \mathrm{a}$ & $-46.7 \mathrm{a}$ & $-59.9 \mathrm{a}$ & $-46.1 \mathrm{a}$ \\
\hline MP-29 & $2.9 \mathrm{a}$ & $9.9 \mathrm{a}$ & $13.1 \mathrm{a}$ & $-40.3 b$ & $-3.7 \mathrm{bc}$ & $9.3 \mathrm{a}$ & $-32.1 \mathrm{a}$ & $-52.0 \mathrm{a}$ & $-58.3 \mathrm{a}$ & $-53.5 \mathrm{a}$ \\
\hline Okinawa & $-0.8 \mathrm{a}$ & $11.9 \mathrm{a}$ & $17.3 \mathrm{a}$ & $-34.7 \mathrm{ab}$ & $11.9 \mathrm{a}$ & $8.1 \mathrm{a}$ & $-31.2 \mathrm{a}$ & $-47.5 \mathrm{a}$ & $-58.7 \mathrm{a}$ & $-45.5 \mathrm{a}$ \\
\hline P-22 & $4.4 \mathrm{a}$ & $8.4 \mathrm{a}$ & $13.7 \mathrm{a}$ & $-31.4 \mathrm{a}$ & $5.5 \mathrm{ab}$ & $14.3 \mathrm{a}$ & $-29.1 \mathrm{a}$ & $-51.7 \mathrm{a}$ & $-57.8 \mathrm{a}$ & $-48.4 \mathrm{a}$ \\
\hline \multicolumn{11}{|l|}{ June } \\
\hline Barton & $-3.8 \mathrm{a}$ & $39.1 \mathrm{a}$ & $0.3 \mathrm{~b}$ & $-49.2 a b$ & $-25.0 \mathrm{~b}$ & $8.6 \mathrm{a}$ & $-50.3 \mathrm{a}$ & $-48.2 \mathrm{a}$ & $-47.0 \mathrm{a}$ & $-72.4 \mathrm{~b}$ \\
\hline Flordaguard & $-13.7 \mathrm{a}$ & $39.6 \mathrm{a}$ & $4.9 \mathrm{~b}$ & $-48.0 \mathrm{ab}$ & $-13.9 \mathrm{a}$ & $10.7 \mathrm{a}$ & $-52.8 \mathrm{a}$ & $-46.6 \mathrm{a}$ & $-52.0 \mathrm{a}$ & $-66.1 \mathrm{ab}$ \\
\hline MP-29 & $-3.9 \mathrm{a}$ & $38.5 \mathrm{a}$ & $4.3 \mathrm{~b}$ & $-51.4 \mathrm{~b}$ & $-20.8 \mathrm{ab}$ & $7.9 \mathrm{a}$ & $-51.0 \mathrm{a}$ & $-46.8 \mathrm{a}$ & $-49.6 \mathrm{a}$ & $-70.8 \mathrm{~b}$ \\
\hline Okinawa & $-6.1 \mathrm{a}$ & $41.7 \mathrm{a}$ & $13.6 \mathrm{a}$ & $-49.9 a b$ & $-12.2 \mathrm{a}$ & $13.8 \mathrm{a}$ & $-49.8 \mathrm{a}$ & $-49.6 \mathrm{a}$ & $-52.8 \mathrm{a}$ & $-61.4 \mathrm{a}$ \\
\hline P-22 & $-8.1 \mathrm{a}$ & $36.9 \mathrm{a}$ & $3.9 \mathrm{~b}$ & $-45.3 \mathrm{a}$ & $-17.1 \mathrm{ab}$ & $10.7 \mathrm{a}$ & $-50.0 \mathrm{a}$ & $-51.2 \mathrm{a}$ & $-49.8 \mathrm{a}$ & $-67.8 \mathrm{ab}$ \\
\hline \multicolumn{11}{|l|}{ October } \\
\hline Barton & $1.8 \mathrm{a}$ & $121.4 \mathrm{a}$ & $52.6 \mathrm{a}$ & $-50.7 \mathrm{a}$ & $-9.1 \mathrm{a}$ & $29.2 \mathrm{a}$ & $-69.8 \mathrm{a}$ & $2.8 \mathrm{a}$ & $-57.4 \mathrm{a}$ & $-42.2 \mathrm{a}$ \\
\hline Flordaguard & $3.5 \mathrm{a}$ & $111.0 \mathrm{a}$ & $44.6 \mathrm{a}$ & $-50.9 \mathrm{a}$ & $-14.5 \mathrm{a}$ & $26.6 \mathrm{a}$ & $-72.3 \mathrm{a}$ & $-11.7 \mathrm{~b}$ & $-58.3 \mathrm{a}$ & $-40.4 \mathrm{a}$ \\
\hline MP-29 & $1.4 \mathrm{a}$ & $115.5 \mathrm{a}$ & $50.2 \mathrm{a}$ & $-51.9 \mathrm{a}$ & $-8.4 \mathrm{a}$ & $26.7 \mathrm{a}$ & $-69.8 \mathrm{a}$ & $-2.2 \mathrm{ab}$ & $-56.4 \mathrm{a}$ & $-40.5 \mathrm{a}$ \\
\hline Okinawa & $0.6 \mathrm{a}$ & $113.0 \mathrm{a}$ & $46.0 \mathrm{a}$ & $-51.2 \mathrm{a}$ & $-9.0 \mathrm{a}$ & $22.7 \mathrm{a}$ & $-72.2 \mathrm{a}$ & $-9.1 \mathrm{ab}$ & $-58.5 \mathrm{a}$ & $-39.6 \mathrm{a}$ \\
\hline $\mathrm{P}-22$ & $0.6 \mathrm{a}$ & $123.3 \mathrm{a}$ & $50.2 \mathrm{a}$ & $-49.1 \mathrm{a}$ & $-10.2 \mathrm{a}$ & $31.4 \mathrm{a}$ & $-70.6 \mathrm{a}$ & $-7.7 \mathrm{ab}$ & $-57.1 \mathrm{a}$ & $-38.2 \mathrm{a}$ \\
\hline
\end{tabular}

$\mathrm{N}=$ nitrogen; $\mathrm{P}=$ phosphorus; $\mathrm{K}=$ potassium; $\mathrm{Mg}=$ magnesium; $\mathrm{Ca}=$ calcium; $\mathrm{B}=$ boron; $\mathrm{Zn}=$ zinc; $\mathrm{Mn}=$ manganese; $\mathrm{Fe}=$ iron; $\mathrm{Cu}=$ copper.

Different letters within columns indicate significant differences among rootstocks within each season to Duncan Multiple Range Test $(P<0.05)$.

and 'Flordaguard', as the second cluster (Fig. 4), showed medium to low N, Fe, and $\mathrm{S}$ values, and medium to high values of $\mathrm{P}, \mathrm{K}, \mathrm{Ca}, \mathrm{Cu}, \mathrm{Mg}$, and $\mathrm{B}$. However, within this cluster, 'Okinawa' had one of the highest leaf $\mathrm{Zn}$ values.

To determine the degree of correlation among elemental nutrients, grouping of foliar nutrient values was performed (Fig. 4). There were strong and moderate correlations among elemental nutrients (Table 5). Leaf B had highly negative and positive correlation with leaf $\mathrm{Mg}$ and $\mathrm{Mn}$, respectively. Leaf $\mathrm{S}$ was positively correlated with $\mathrm{N}$ and negatively correlated with $\mathrm{Ca}$.

\section{Discussion}

The rootstock influences macro- and micronutrient absorption and transport in fruit crops. In our case, leaf nutrient concentration of
'UFSun' peach was affected by the various rootstock treatments (Table 3). Some authors have previously confirmed important influences of rootstock on the mineral uptake by trees (Jiménez et al., 2004, 2007). Also, Mayer et al. (2015) and Mestre et al. (2015) reported the influence of different Prunus rootstocks on the nutrient status of the scion. In general, rootstocks differ in their root architecture, root cation exchange capacities, and root exudates, which can, in turn, influence leaf nutrient concentrations (Kucukyumuk and Erdal, 2011).

In our case, some leaf macronutrient levels differed across rootstocks. Several authors concluded that macronutrient concentration was more influenced than leaf micronutrients on various rootstocks (Moreno et al., 1996). Therefore, as previously reported (Milosevic and Milosevic, 2010; Rosati et al., 1996), it can be concluded that various rootstocks have different uptake ability of macronutrients. Inherent ca- pacity of the different rootstocks to major nutrient absorption and translocation is different (Meland, 2010; Mestre et al., 2015, 2017). In the present work, leaf concentrations of most of the nutrients studied were not significantly affected by rootstock, with the exception of a few elements. Different genotypes of rootstocks can restrict nutrient translocation because of variation in xylem dimension (Tombesi et al., 2011), and morphological and physiological aspects of root morphology, which can directly contribute to ion absorption and translocation, and redistribution (Hell and Stephan, 2003), and, consequently, to the final nutrient concentration for plant growth (Nawaz et al., 2016). Thereby, it is possible to select most efficient rootstocks in capturing and translocating mineral elements in the soil with more effective combinations with fertilizer (Savvas et al., 2009). A negative correlation between the concentration of $\mathrm{K}$ and $\mathrm{Mg}$ in the peach leaf 
was observed (Table 5). 'UFSun' scion on all rootstocks had lower leaf $\mathrm{Mg}$ values than the optimum reference values (Table 4). Deficiency of leaf $\mathrm{Mg}$ can be induced by antagonism with other cations such as $\mathrm{Zn}, \mathrm{Fe}$, and $\mathrm{K}$ (Table 5), which is in agreement with other findings (Milošević et al., 2013).

Leaf micronutrient concentration of the scion showed a great variation and differed significantly across rootstocks and increased leaf concentrations in certain months (Fig. 1). On the basis of our results, we can say that 'Flordaguard' and 'Okinawa' rootstock have significantly less uptake capacity for Fe; 'P-22' for $\mathrm{Mn}$; 'Barton' for $\mathrm{Cu}$; 'Flordaguard' for Zn; and 'MP-29' for B than other

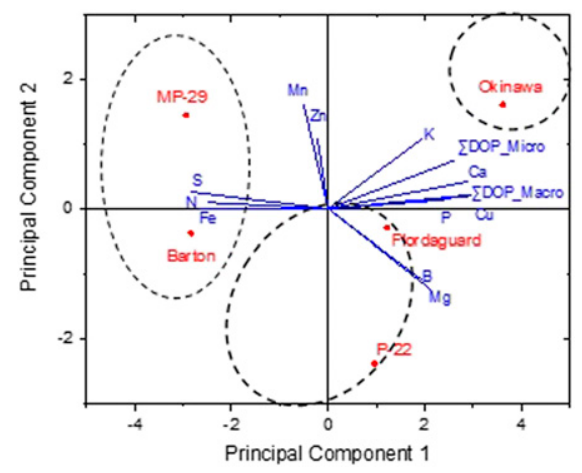

Fig. 3. Principal component analysis for leaf nutrients evaluated on 'UFSun' cultivar grafted on various rootstocks. rootstocks (Table 3). According to Gonzalo et al. (2011), Prunus rootstock can influence ion transporters related to nutrient absorption and translocation to the aerial part of the tree, which is favoring ion absorption. Therefore, in this way, rootstock contributes to proper vigor and productivity provided to the scion along with the efficiency in absorption and transportation of nutrients (Nawaz et al., 2016). The deficiency of Fe and $\mathrm{Zn}$ can be attributed to the antagonistic effect of P:Fe and $\mathrm{Mg}: \mathrm{Zn}$, as previously reported by (Milošević et al., 2015). Malvi (2011) concluded that uptake of cationic micronutrients such as Fe and Mn can be reduced by an excess amount of P. A lower efficiency (in absorbing and translocating $\mathrm{Zn}$ ) was also observed on some rootstocks (Table 3), which is in agreement with findings from Mayer et al. (2015) and Reighard et al. (2012). Stone fruit rootstocks had varying ability to absorb and translocate zinc, due to different root system architecture and susceptibility to mycorrhizal infection (Havlin et al., 2005).

DOP index of mineral elements was determined to evaluate the optimum nutrition concentration (Table 4). Negative value of DOP indexes $(\mathrm{DOP}<0)$ is related to problems in soil availability and nutrient uptake (Leece and den Ende, 1975). In the present work, peach on all rootstocks tested tended to have a DOP values for $P, K$, and $B$ close to the normal level on all sampling dates except December, which had negative value (DOP $<$

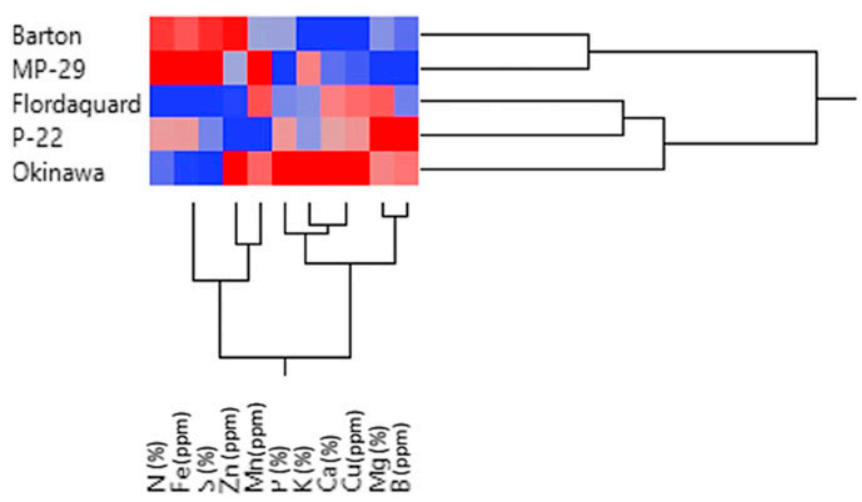

Fig. 4. Cluster display of the various rootstocks, in terms of macronutrient and micronutrient concentrations in 'UFSun' leaves. Rootstocks grouped by similarities in mean mineral nutrient concentration values.
$0)$. Significant differences for macronutrients were observed among rootstocks for $\Sigma \mathrm{DOP}$ index in various months (Fig. 2). The highest $\Sigma$ DOP index values were in December and October, and the lowest in April and June In contrast, Zarrouk et al. (2005) and Jiménez et al. (2007) reported that there were no statistically significant differences for nutritional balance values among rootstocks for peach and cherry, respectively. $\Sigma$ DOP index for micronutrients varied significantly across rootstocks (Fig. 2).

Multivariate analysis with the PCA model was determined to evaluate a general overview of the two UFSun peach cultivars budded on the different rootstocks to identify the best adapted rootstock to the soil conditions of Florida (Fig. 3). There was a clear separation among rootstocks. 'MP-29' and 'Barton', 'Flordaguard' and 'P-22', and 'Okinawa' rootstocks were separated into three groups. A cluster analysis of rootstock effects on macronutrients and micronutrients in leaves of 'UFSun' scions showed that 'Okinawa' rootstock stands apart from the other rootstocks (Fig. 4). The other groups generated by the analysis comprise intermediary rootstocks, which favored some nutrients over others. It must be emphasized that the performance of the different rootstocks was not consistent for all nutrients (Table 3).

\section{Conclusion}

Rootstock affected the seasonal variation in nutrient concentration in leaves of peach. For all rootstocks, concentrations of foliar microelements decreased during December, and then displayed an increasing trend through October. The results of this study verify that the rootstocks tested differ in their suitability for fruit production, which offers the possibility of a technically based choice of rootstock, which could optimize nutrition absorption and translocation and, thereby, enable the reduction in the amounts of fertilizers applied. Leaf nutrient accumulation was nonuniform and resulted in nutrient deviation from optimum values. The DOP index showed a nutrient imbalance in all rootstocks. The results observed in this trial showed that with optimum leaf $\mathrm{Ca}, \mathrm{K}$, and, $\mathrm{Mg}$ concentration, 'Okinawa' and 'Flordaguard' rootstock might be a better rootstock candidate for orchards established on sandy soils in

Table 5. Pearson's correlation coefficients among leaf mineral nutrients on five different peach rootstocks grafted on cultivar UFSun.

\begin{tabular}{|c|c|c|c|c|c|c|c|c|c|c|}
\hline & $\mathrm{N}$ & $\mathrm{P}$ & $\mathrm{K}$ & $\mathrm{Mg}$ & $\mathrm{Ca}$ & $S$ & B & $\mathrm{Zn}$ & $\mathrm{Mn}$ & $\mathrm{Fe}$ \\
\hline $\bar{P}$ & -0.53 & & & & & & & & & \\
\hline $\mathrm{Mg}$ & -0.67 & 0.55 & -0.01 & & & & & & & \\
\hline $\mathrm{Ca}$ & -0.76 & 0.74 & 0.82 & 0.50 & & & & & & \\
\hline B & -0.31 & 0.57 & 0.22 & 0.83 & 0.50 & -0.53 & & & & \\
\hline $\mathrm{Zn}$ & 0.26 & 0.46 & 0.18 & -0.39 & -0.16 & 0.25 & -0.27 & & & \\
\hline $\mathrm{Mn}$ & -0.03 & -0.20 & 0.31 & -0.71 & 0.03 & 0.13 & -0.83 & 0.35 & & \\
\hline
\end{tabular}

$\mathrm{N}=$ nitrogen $; \mathrm{P}=$ phosphorus $; \mathrm{K}=$ potassium; $\mathrm{Mg}=$ magnesium; $\mathrm{Ca}=$ calcium; $\mathrm{S}=$ sulfate $; \mathrm{B}=$ boron; $\mathrm{Zn}=$ zinc $; \mathrm{Mn}=$ manganese $; \mathrm{Fe}=$ iron; $\mathrm{Cu}=$ copper.

*,**Significant at $P<0.05$ or 0.01 , respectively. 
Florida. However, there is still a need for further investigation of horticultural potential of these rootstocks, which will be used to develop a better technically based choice of peach rootstock.

\section{Literature Cited}

Aguirre, P.B., Y.K. Al-Hinai, T.R. Roper, and A.R. Krueger. 2001. Apple tree rootstock and fertilizer application timing affect nitrogen uptake. HortScience 36:1202-1205.

Ahmed, W., M.A. Nawaz, M.A. Iqbal, and M. Khan. 2007. Effect of different rootstocks on plant nutrient status and yield in Kinnow mandarin (Citrus reticulata Blanco). Pak. J. Bot. 39:1779-1786.

Amiri, M.E. and E. Fallahi. 2009. Impact of animal manure on soil chemistry, mineral nutrients, yield, and fruit quality in 'Golden Delicious' apple. J. Plant Nutr. 32:610-617.

Beckman, T.G., J.X. Chaparro, and W.B. Sherman. 2012. 'MP-29', a clonal interspecific hybrid rootstock for peach. HortScience 47:128-131.

Boyhan, G., J. Norton, and J. Pitts. 1995. Establishment, growth, and foliar nutrient content of plum trees on various rootstocks. HortScience 30:219-221.

Castle, W.S. 1987. Citrus rootstocks. In: R.C. Rom and R.F. Carlson (eds.). Rootstocks for fruit crops. John Wiley and Sons, New York, NY.

Chatzissavvidis, C.A., I.N. Therios, and A.N. Molassiotis. 2005. Seasonal variation of nutritional status of olive plants as affected by boron concentration in nutrient solution. $\mathrm{J}$. Plant Nutr. 28:309-321.

Durán-Zuazo, V.H., J. Aguilar-Ruiz, and A. MartínezRaya. 2005. Fruit yield, plant growth and nutrient status in mango. Intl. J. Fruit Sci. 5:3-21.

Facteau, T., N. Chestnut, and K. Rowe. 1996. Tree, fruit size and yield of 'Bing' sweet cherry as influenced by rootstock, replant area, and training system. Scientia Hort. 67:13-26.

Fallahi, E., W.M. Colt, B. Fallahi, and I.-J. Chun. 2002. The importance of apple rootstocks on tree growth, yield, fruit quality, leaf nutrition, and photosynthesis with an emphasis on 'Fuji'. HortTechnology 12:38-44.

Gonzalo, M.J., M.Á. Moreno, and Y. Gogorcena. 2011. Physiological responses and differential gene expression in Prunus rootstocks under iron deficiency conditions. J. Plant Physiol. 168:887-893.

Havlin, J.L., J.D. Beaton, S.L. Tisdale, and W. Nelson. 2005. Soil fertility and fertilizers: An introduction to nutrient management. Pearson Prentice Hall, Upper Saddle River, NJ.

Hell, R. and U.W. Stephan. 2003. Iron uptake, trafficking and homeostasis in plants. Planta 216:541-551.

Isaac, R. and W. Johnson. 1985. Elemental analysis of plant tissue by plasma emission spectroscopy: Collaborative study. J. Assoc. Off. Anal. Chem. 68:3.

Jimenes, I.M., N.A. Mayer, C.T. dos Santos Dias, J.A. Scarpare Filho, and S.R. da Silva. 2018. Influence of clonal rootstocks on leaf nutrient content, vigor and productivity of young 'Sunraycer' nectarine trees. Scientia Hort. 235:279-285.

Jiménez, S., A. Garín, Y. Gogorcena, J.A. Betrán, and M.A. Moreno. 2004. Flower and foliar analysis for prognosis of sweet cherry nutrition: Influence of different rootstocks. J. Plant Nutr. 27:701-712.

Jiménez, S., J. Pinochet, Y. Gogorcena, J. Betrán, and M. Moreno. 2007. Influence of different vigour cherry rootstocks on leaves and shoots mineral composition. Scientia Hort. 112:73-79.
Knowles, J., W. Dozier, Jr., C. Evans, C. Carlton, and J. McGuire. 1984. Peach rootstock influence on foliar and dormant stem nutrient content. J. Amer. Soc. Hort. Sci 109:440-444.

Kucukyumuk, Z. and I. Erdal. 2011. Rootstock and cultivar effect on mineral nutrition, seasonal nutrient variation and correlations among leaf, flower and fruit nutrient concentrations in apple trees. Bulg. J. Agr. Sci. 17:633-641.

Küçükyumuk, Z., C. Küçükyumuk, İ. Erdal, and F. Eraslan. 2012. Seasonal variations and different irrigation programs on nutrient concentrations of 'Starkrimson Delicious' apple variety. World Academy of Science. Engineering and Technology 71:952-955.

Kumar, P., S.K. Sharma, and A. Kumar. 2017. Foliar nutritive fluids affect generative potential of apples: Multilocation DOP indexing and PCA studies under dry temperate agro-climatic conditions of north-west Himalaya. Scientia Hort. 218:265-274.

Kviklys, D., N. Kvikliene, A. Bite, J. Lepsis, T. Univer, N. Univer, N. Uselis, J. Lanauskas, and L. Buskienè. 2012. Baltic fruit rootstock studies: Evaluation of 12 apple rootstocks in NorthEast Europe. Hort. Sci. 39:1-7.

Leece, D. and B. den Ende. 1975. Diagnostic leaf analysis for stone fruit. 6. Apricot. Aust. J. Expt. Agr. 15:123-128.

Malvi, U.R. 2011. Interaction of micronutrients with major nutrients with special reference to potassium. Karnataka J. Agr. Sci. 24:106-109.

Maquilan, M.A.D. 2017. Rootstock breeding for resistance to the peach root-knot nematode (Meloidogyne floridensis). Univ. Florida, Gainesville, Ph.D. Diss. p. 113.

Mayer, N.A., B. Ueno, and V.A.L.D. Silva. 2015 Leaf nutrient content of peach on five rootstocks. Rev. Bras. Frutic. 37:1045-1052.

Meland, M. 2010. Performance of six European plum cultivars on four plum rootstocks growing in a northern climate. Acta Agr. Scand. B Soil Plant Sci. 60:381-387.

Mestre, L., M. Moreno, G. Reig, and J. Betrán. 2017. Influence of plum rootstocks on agronomic performance, leaf mineral nutrition and fruit quality of 'Catherina' peach cultivar in heavy-calcareous soil conditions. Spanish Journal of Agricultural Research 15(1):e0901.

Mestre, L., G. Reig, J.A. Betrán, J. Pinochet, and M.Á. Moreno. 2015. Influence of peach-almond hybrids and plum-based rootstocks on mineral nutrition and yield characteristics of 'Big Top' nectarine in replant and heavy-calcareous soil conditions. Scientia Hort. 192:475-481.

Milosevic, T. and N. Milosevic. 2011. Seasonal changes in micronutrients concentrations in leaves of apricot trees influenced by different interstocks. Agrochimica 55:1-14.

Milošević, T., N. Milošević, and I. Glišić. 2015. Apricot vegetative growth, tree mortality, productivity, fruit quality and leaf nutrient composition as affected by Myrobalan rootstock and Blackthorn Inter-Stem. Erwerbs-Obstbau 57:77-91.

Milošević, T., N. Milošević, I. Glišić, L. BoškovićRakočević, and J. Milivojević. 2013. Fertilization effect on trees and fruits characteristics and leaf nutrient status of apricots which are grown at Cacak region (Serbia). Scientia Hort. 164:112-123.

Montañés, L., L. Heras, and M. Sanz. 1991. Desviación del óptimo porcentual (DOP): Nuevo índice para la interpretación del análisis vegetal. An. Aula Dei 20:93-107.
Moreno, M., L. Montañés, M. Tabuenca, and R. Cambra. 1996. The performance of Adara as a cherry rootstock. Scientia Hort. 65:85-91.

Mylavarapu, R., W. Harris, and G. Hochmuth. 2016. Agricultural soils of Florida. No. SL441. University of Florida Institute of Food and Agricultural Sciences, Gainesville. 7 p. $<$ https://edis. ifas.ufl.edu/pdffiles/SS/SS65500.pdf>.

Nachtigall, G.R. and A.R. Dechen. 2006. Seasonality of nutrients in leaves and fruits of apple trees. Sci. Agr. 63:493-501.

Nawaz, M.A., M. Imtiaz, Q. Kong, F. Cheng, W. Ahmed, Y. Huang, and Z. Bie. 2016. Grafting: A technique to modify ion accumulation in horticultural crops. Front. Plant Sci. 7:1457.

North, M. and N. Cook. 2006. Effect of six rootstocks on 'Forelle' pear tree growth, production, fruit quality and leaf mineral content. Acta Hort 772:97-103.

Reighard, G., W. Bridges, B. Rauh, and N. Mayer. 2012. Prunus rootstocks influence peach leaf and fruit nutrient content. Acta Hort 984:117-124.

Reuter, D. 1997. Temperate and tropical crops, p. 83-278. In: D.J. Reuter and J.B. Robinson (eds.). Plant analysis: An interpretation manual. CSIRO Publishing, Collingwood, Vic., Australia.

Rosati, A., T. DeJong, and S. Southwick. 1996. Comparison of leaf mineral content, carbon assimilation and stem water potential of two apricot (Prunus armeniaca) cultivars grafted on 'Citation' and 'Marianna 2624' rootstocks. Acta Hort 451:263-268.

Savvas, D., D. Papastavrou, G. Ntatsi, A. Ropokis, C. Olympios, H. Hartmann, and D. Schwarz. 2009. Interactive effects of grafting and manganese supply on growth, yield, and nutrient uptake by tomato. HortScience 44:1978-1982.

Sharpe, R., C. Hesse, B. Lownsbery, and C. Hansen. 1969. Breeding peaches for root-knot nematode resistance. J. Amer. Soc. Hort. Sci. 94:209-212.

Sharpe, R.H. 1957. Okinawa peach shows promising resistance to root-knot nematodes. Florida Agr. Expt. Sta. J. 657:320-322.

Sherman, W., P.M. Lyrene, and R. Sharpe. 1991. Flordaguard peach rootstock. HortScience 26:427-428.

Tomala, K., J. Andziak, K. Jeziorek, and R. Dziuban. 2008. Influence of rootstock on the quality of 'Jonagold' apples at harvest and after storage. J. Fruit Ornam. Plant Res. 16:31-38.

Tombesi, S., A. Almehdi, and T.M. DeJong. 2011. Phenotyping vigour control capacity of new peach rootstocks by xylem vessel analysis. Scientia Hort. 127:353-357.

Tsipouridis, C. and T. Thomidis. 2005. Effect of 14 peach rootstocks on the yield, fruit quality, mortality, girth expansion and resistance to frost damages of May Crest peach variety and their susceptibility on Phytophthora citrophthora. Scientia Hort. 103:421-428.

Wünsche, J.N., D.H. Greer, W.A. Laing, and J.W Palmer. 2005. Physiological and biochemical leaf and tree responses to crop load in apple. Tree Physiol. 25:1253-1263.

Zarrouk, O., Y. Gogorcena, J. Gómez-Aparisi, J. Betrán, and M. Moreno. 2005. Influence of almondx peach hybrids rootstocks on flower and leaf mineral concentration, yield and vigour of two peach cultivars. Scientia Hort 106:502-514.

Zhang, Z.-K., L. Hua, Z. Yu, Z.-J. Huang, C. Kun, and S.-Q. Liu. 2010. Grafting enhances copper tolerance of cucumber through regulating nutrient uptake and antioxidative system. Agr. Sci. China 9:1758-1770. 